\title{
Phosphorus dynamics in cultures and natural populations of Trichodesmium spp.
}

\author{
Margaret R. Mulholland ${ }^{1, *}$, Sheri Floge ${ }^{2}$, Edward J. Carpenter ${ }^{3}$, Douglas G. Capone ${ }^{4}$ \\ ${ }^{1}$ Department of Ocean, Earth and Atmospheric Sciences, Old Dominion University, Norfolk, Virginia 23529-0276, USA \\ ${ }^{2}$ School of Marine Sciences, University of Maine, Darling Marine Center, Walpole, Maine 04573, USA \\ ${ }^{3}$ Romberg Tiburon Center for Environmental Studies, San Francisco State University, Tiburon, California 94920, USA \\ ${ }^{4}$ Wrigley Institute of Environmental Studies and Department of Biological Sciences, University of Southern California, \\ Los Angeles, California 90089, USA
}

\begin{abstract}
Trichodesmium spp. fix atmospheric $\mathrm{N}_{2}$ and so an element other than $\mathrm{N}$ limits production by these species in the oligotrophic ocean. Because dissolved inorganic phosphorus (DIP) is in short supply in many marine systems, it has been hypothesized that $\mathrm{P}$ is a growth-limiting nutrient for these species in nature. However, Trichodesmium is capable of hydrolyzing dissolved organic $\mathrm{P}$ (DOP) compounds and the inorganic products from hydrolysis may provide an additional source of $\mathrm{P}$ for growth. We investigated $\mathrm{P}$ dynamics and alkaline phosphatase activity in cultures and natural populations of Trichodesmium from the Atlantic Ocean and the north coast of Australia to determine whether hydrolysis of DOP could supply enough P to fuel growth. During the Atlantic cruise, concentrations of DIP were lower and chlorophyll ( $\mathrm{chl}$ a)-specific rates of alkaline phosphatase activity by Trichodesmium were higher than during the Australian transect. However, because Trichodesmium were much more abundant during the Australian transect, where they represented the bulk of the surface chl a biomass, total water column rates of alkaline phosphatase activity were higher along the Australian transect than in the Atlantic. In both systems, DOP could potentially supply a significant portion of the cellular P necessary for growth. In cultures and natural populations, alkaline phosphatase activity was inhibited when DIP was present and increased in the presence of DOP. Cultures of Trichodesmium IMS101 grew equally well on media enriched with DOP or DIP at all but the highest enrichment levels. From these studies, we conclude that if the supply of appropriate DOP substrates is adequate, DOP can represent an important P source for Trichodesmium growth which should be included in estimates of $\mathrm{P}$ availability in surface waters.
\end{abstract}

KEY WORDS: Trichodesmium - Alkaline phosphatase activity $\cdot$ P dynamics $~$ Dissolved organic phosphorus

\section{INTRODUCTION}

Trichodesmium spp. occur throughout tropical and subtropical seas where they can use $\mathrm{N}_{2}$ to support net growth (Capone et al. 1997, Carpenter et al. 1997). $\mathrm{N}_{2}$ fixation is a source of new N (sensu Dugdale \& Goering 1967) and therefore, Trichodesmium can contribute to the alleviation of system-wide $\mathrm{N}$ limitation. Because

*E-mail: mmulholl@odu.edu they fix $\mathrm{N}_{2}$, they are not $\mathrm{N}$-limited and the productivity of these species in natural systems is limited by other physical, chemical and/or biological factors.

It has been hypothesized that the availability of some other dissolved nutrient or trace element limits growth of diazotrophs in the ocean. Inorganic $\mathrm{N}$ (e.g. $\mathrm{NH}_{4}{ }^{+}$and $\mathrm{NO}_{3}{ }^{-}$) and $\mathrm{P}$ (e.g. $\mathrm{PO}_{4}{ }^{3-}$ ) are present at low concentrations or at the limits of analytical detection in many oceanic regions (e.g. Wu et al. 2000, Karl et al. 2001). Trichodesmium use $\mathrm{N}_{2}$ as their primary $\mathrm{N}$ source and therefore, it has been suggested that dissolved inor- 
ganic P (DIP) may limit the growth of diazotrophs in some oceanic regions (e.g. Letelier \& Karl 1996, 1998, Karl 1999, Sañudo-Wilhelmy et al. 2001). Alternatively, $\mathrm{Fe}$ is required for growth and for $\mathrm{N}_{2}$ fixation and is also sparse in oceanic regions that are far from continental Fe sources leading to the contention that dissolved Fe may limits productivity in other regions (e.g. Reuter et al. 1992, Falkowski 1997). In this paper, we will examine $\mathrm{P}$ limitation of Trichodesmium growth.

While cells can fix $\mathrm{N}_{2}$ from the atmosphere to satisfy their $\mathrm{N}$ demand for growth, $\mathrm{P}$ flux from deep water may be insufficient to satisfy the P requirements for growth. In support of this theory, high particulate $\mathrm{N}(\mathrm{PN})$ :particulate $\mathrm{P}(\mathrm{PP})$ ratios have been observed in natural populations of Trichodesmium from the Pacific Ocean (Karl et al. 1992, 1997, 2001, Letelier \& Karl 1996). High rates of alkaline phosphatase activity (APA) have been observed in association with Trichodesmium colonies (Yentsch et al. 1972, McCarthy \& Carpenter 1979, Stihl et al. 2001) and extracellular hydrolysis of dissolved organic P (DOP) from this pathway may provide cells with additional $P$ for growth. This cell surface enzyme has been used as an indicator of P limitation in other systems (Perry 1972, Ammerman 1993). Although APA has been observed to be associated with Trichodesmium colonies in nature, $\mathrm{P}$ uptake and cycling have not been widely investigated in natural marine and culture systems to determine whether these species have the physiological capacity to use DOP.

We compared ambient rates of APA with DIP and DOP concentrations in 2 oceanic regions where Trichodesmium were abundant to assess whether these organisms could potentially meet their $\mathrm{P}$ demand for growth by hydrolyzing DOP compounds. In addition, controls on APA were investigated in both natural and cultured populations of Trichodesmium to determine the nutrient conditions promoting this activity. In natural populations of Trichodesmium spp., we compared rates of APA with respect to DIP concentrations in the
Atlantic and with respect to DIP and DOP in a transect along the north coast of Australia. To ascertain the capacity of cells to use organic P for growth, we measured APA, inorganic and organic P concentrations, cellular P and cellular PN:PP molar ratios in cultures of Trichodesmium IMS101 growing under various inorganic and organic $\mathrm{P}$ regimes.

\section{MATERIALS AND METHODS}

Trichodesmium IMS101 was grown in batch cultures on defined artificial medium (YBCII) with no added $\mathrm{N}$ (Chen et al. 1996) and various concentrations of $\mathrm{PO}_{4}{ }^{3-}$, Na-glycerolphosphate (glycerol-P) or glucose-6-phosphate. Cultures were grown under low light $(100 \mu \mathrm{mol}$ quanta $\mathrm{m}^{-2} \mathrm{~s}^{-1}$ ) supplied with diel periodicity on a 12:12 h light:dark regime, and were maintained for several generations on each medium before beginning experiments. Growth curves were constructed, and P dynamics were examined over a growth cycle and over a diel cycle during exponential growth for each $\mathrm{P}$ regime tested. Growth rates were estimated based on chlorophyll a (chl a) concentrations (Mackinney 1941) and microscopic enumeration of cell number.

APA, inorganic nutrients and cellular P concentrations were measured in natural populations of Trichodesmium during a transect along the north coast of Australia, from Townsville to Broome, aboard the RV 'Maurice Ewing' in November 1999 (Fig. 1). In addition, APA was measured in incubations enriched with $\mathrm{N}$ and $\mathrm{P}$ compounds to determine how nutrients affect this activity. We had previously measured APA and surface $\mathrm{PO}_{4}{ }^{3-}$ concentrations during a cruise in the subtropical North Atlantic aboard the RV 'Gyre' in May 1994 (Fig. 2). Field results were compared to determine the contribution of Trichodesmium to water column DOP hydrolysis under ambient and enriched nutrient conditions.

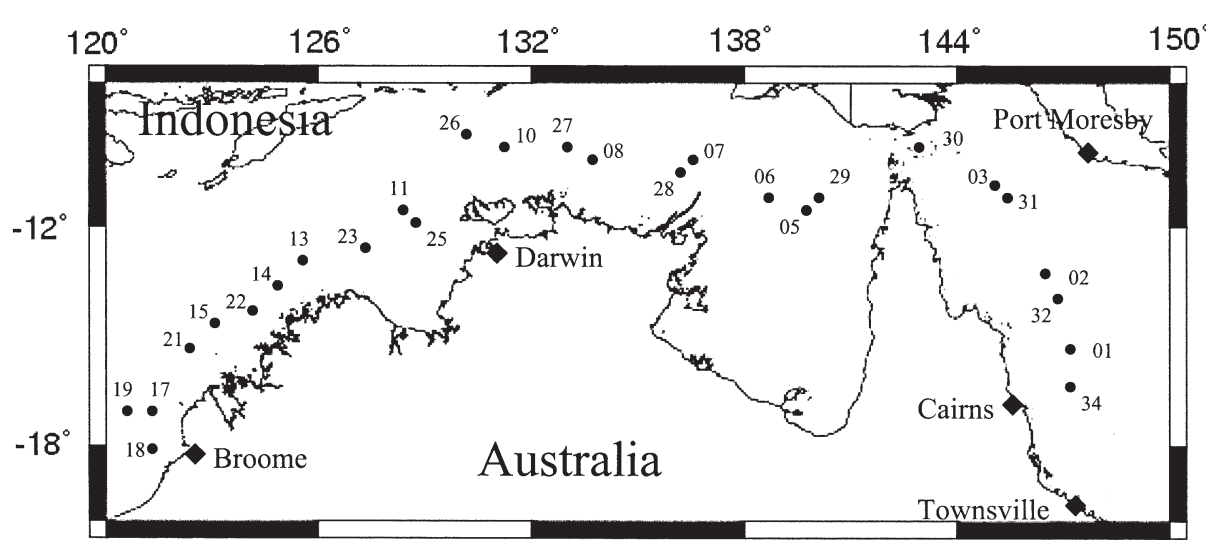

Fig. 1. Transect of the north coast of Australia made aboard the RV 'Maurice Ewing' in November 1999. Locations of stations are indicated with circles 
Fig. 2. Transect into the Western subtropical North Atlantic Ocean made aboard the RV 'Gyre' in May 1994. Locations of stations are indicated with circles

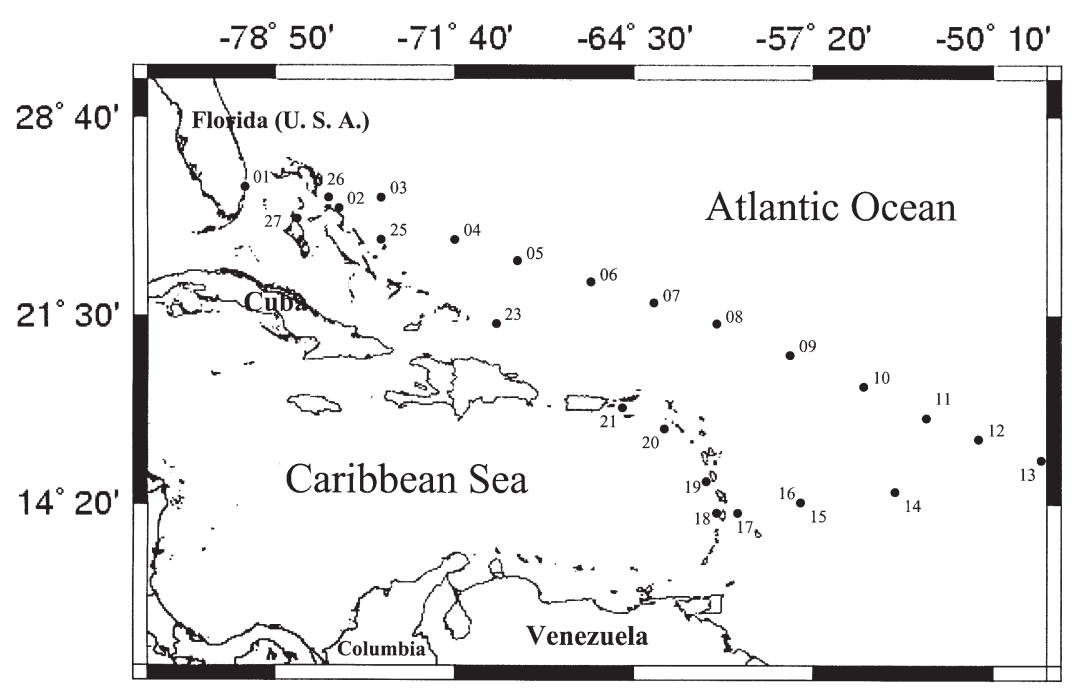

In field experiments, incubations included whole seawater, with and without added Trichodesmium colonies, and with additions of $\mathrm{NH}_{4}{ }^{+}, \mathrm{PO}_{4}{ }^{3-}$ or $\mathrm{Na}$ glycerolphosphate. In the laboratory, incubations included whole culture and filtered $(<5.0 \mu \mathrm{m})$ controls from cultures grown on 1,3 or $50 \mu \mathrm{M}$ of $\mathrm{PO}_{4}{ }^{3-}$ or Naglycerolphosphate.

Alkaline phosphatase activity. APA was measured using 4-methyumbellyferyl phosphate (MUF-P) (Ammerman 1993). Kinetic studies were done to determine the optimum concentration for MUF-P substrate additions and optimum length for incubations in each environment. Assays were initiated by adding $100 \mathrm{nM}$ (field studies) or $1 \mu \mathrm{M}$ (culture studies) MUF-P to assay bottles. Killed controls and hydrolysis of MUF-P was monitored under ambient light and temperature conditions either in the laboratory incubators or in on-deck incubators equipped with running seawater and neutral density screening. Immediately following the addition of MUF-P, and at 30 min intervals thereafter for a period of $4 \mathrm{~h}$, a sample was extracted and analyzed fluorometrically to measure MUF-P hydrolysis against a MUF standard. Turnover times for MUF-P were calculated (Ammerman 1993) and DOP hydrolysis estimated assuming the entire DOP pool was available for hydrolysis.

Elemental composition. At each sampling point, two $10 \mathrm{ml}$ samples of cultures or 10 to 30 colonies from a natural population were filtered for elemental analysis. PP and PN samples were digested using persulfate (Raimbault et al. 1999) and analyzed using either a Technicon II autoanalyzer or a Lachat FIA system. PN results are reported elsewhere and will not be discussed here (see J. Krauk et al. unpubl.).

Dissolved nutrients. DIP and DOP measurements were made on GF/F filtered samples collected at each sampling point in cultures and at each station in the field. Inorganic $\mathrm{P}$, as $\mathrm{PO}_{4}{ }^{3-}$, was measured using the method of Parsons et al. (1984) or by autoanalysis using a Lachat or Technicon II autoanalyzer system. Total dissolved P (TDP) was measured after persulfate oxidation according to the method of Valderrama (1981) and DOP estimated after subtraction of DIP.

\section{RESULTS}

\section{Natural populations}

The per colony rates of MUF-P hydrolysis by Trichodesmium were up to 350 times higher in the subtropical Atlantic Ocean during the cruise in May 1994 (Table 1) than in the tropical seas along the north coast of Australia during the cruise in November 1999 (data not shown). Per colony rates of MUF-P hydrolysis ranged from 0.03 to $0.24 \mu \mathrm{mol} \mu \mathrm{g} \mathrm{chl} a^{-1} \mathrm{~h}^{-1}$ in natural populations from the subtropical North Atlantic (Table 1); rates which were comparable to the lowest rates measured by Stihl et al. (2001) in the Gulf of Aqaba using another organic substrate, $p$-nitrophenylphosphate (PNPP). By contrast, when we calculated per colony rates of APA based on the turnover time of MUF-P and ambient DOP concentrations along the north coast of Australia, the highest rates $\left(0.013 \mu \mathrm{mol} \mu \mathrm{g} \mathrm{chl} a^{-1} \mathrm{~h}^{-1}\right)$ were an order of magnitude or more lower than those measured in Trichodesmium populations from the Gulf of Aqaba in the other recent study (Stihl et al. 2001). These results suggest that APA varies among basins, even those with low or undetectable DIP concentrations. One possible explanation for the differences is that the Gulf of Aqaba study used a spectrophotometric assay in which high concentrations $(0.4 \mathrm{mM})$ of PNPP were added as the hydrolysis substrate (Stihl et al. 2001). In addition, the assay was 
Table 1. Dissolved inorganic P (DIP) concentrations and alkaline phosphatase activity (APA) during a cruise transect in the subtropical Western North Atlantic in 1994. Standard deviations are in parentheses. DL indicates the concentration was at the limit of analytical detection $(0.01 \mu \mathrm{M})$

\begin{tabular}{|c|c|c|c|c|}
\hline \multirow[t]{2}{*}{ Stn } & \multirow[t]{2}{*}{ Date } & \multirow{2}{*}{$\begin{array}{l}\text { DIP } \\
(\mu \mathrm{M})\end{array}$} & \multicolumn{2}{|c|}{ APA } \\
\hline & & & $\begin{array}{l}\text { nmol MUF-P hydro- } \\
\text { lyzed (colony }{ }^{-1} \mathrm{~h}^{-1} \text { ) }\end{array}$ & $\begin{array}{l}\mu \text { mol MUF-P hydro- } \\
\text { lyzed }\left(\mu \mathrm{g} \mathrm{chl} \mathrm{a}^{-1} \mathrm{~h}^{-1}\right)^{*}\end{array}$ \\
\hline 3 & 23 May & 0.01 & $4.71(1.09)$ & 0.15 \\
\hline 3 & 23 May & 0.02 & $3.13(0.35)$ & 0.10 \\
\hline 4 & 24 May & DL & $7.76(0.81)$ & 0.24 \\
\hline 5 & 25 May & DL & $1.78(1.30)$ & 0.06 \\
\hline 6 & 26 May & DL & $7.12(0.80)$ & 0.22 \\
\hline 7 & 27 May & 0.03 & $2.67(0.11)$ & 0.08 \\
\hline 7 & 27 May & 0.02 & $1.14(0.62)$ & 0.04 \\
\hline 8 & 28 May & 0.01 & $0.84(0.15)$ & 0.03 \\
\hline 9 & 29 Мау & 0.01 & $2.40(1.20)$ & 0.08 \\
\hline
\end{tabular}

vember 1999 (Table 2). We pooled rates of APA from the Australia cruise and compared them to concentrations of DIP; rates of APA were higher when ambient DIP concentrations were lower (e.g. $<1.0 \mu \mathrm{M}$ ) and decreased as concentrations of DIP increased (Fig. 3).

Despite measurable DIP concentrations (Table 2), PN:PP molar ratios of Trichodesmium were always 25 or higher in waters along the north coast of Australia (results reported elsewhere; Krauk et al. in prep.). In these populations, we found no correlations between Trichodesmium colony abundance, per colony rates of APA, $\mathrm{P}_{\text {colony }}{ }^{-1}$, DIP concentration, or DOP concentration and the PN:PP molar ratio of Trichodesmium (all $\mathrm{R}^{2}<0.1$;

longer in duration (12 h) and conducted at high temperatures $\left(37^{\circ} \mathrm{C}\right)$ and so APA rates reported may not reflect in situ rates of DOP hydrolysis.

Even though rates appeared to be lower on a per unit chl a basis and the biomass of individual colonies was 50 to $67 \%$ smaller along the Australia transect than in the Atlantic (resulting in a lower per colony estimates), per volume seawater rates of APA were much higher along the Australia transect because Trichodesmium were much more abundant (100s to 1000 s of colonies $\mathrm{l}^{-1}$ in Australia vs $<1$ colony $\mathrm{l}^{-1}$ in the Atlantic; E. Carpenter et al. unpubl.). Lower DIP concentrations in the Atlantic Ocean (Table 1) may have stimulated APA on a per colony basis in this basin relative to the Australian coast, where DIP concentrations of at least $0.1 \mu \mathrm{g}$ were always detectable in the surface waters throughout No- data not shown). However, rates of APA were high in bulk seawater that did not contain Trichodesmium, ranging from 0.006 to $0.955 \mu \mathrm{mol} \mu \mathrm{g} \mathrm{chl} \mathrm{a}^{-1} \mathrm{~h}^{-1}$ (Table 2). While chl a concentrations in the surface waters were typical of oligotrophic environments, there were a variety of large dinoflagellates in the water column and subsurface chl a maxima; consequently, other taxa could have produced a substantial amount of enzyme. In general, however, Trichodesmium accounted for the bulk of the water column chl $a$ and so could account for the bulk of the water column enzyme activity on a volumetric basis.

To determine whether APA could supply any or all of the $\mathrm{P}$ demand for growth, we calculated the hypothetical turnover rates of Trichodesmium $\mathrm{P}$ biomass based on the observed P biomass of colonies, DOP concentra-

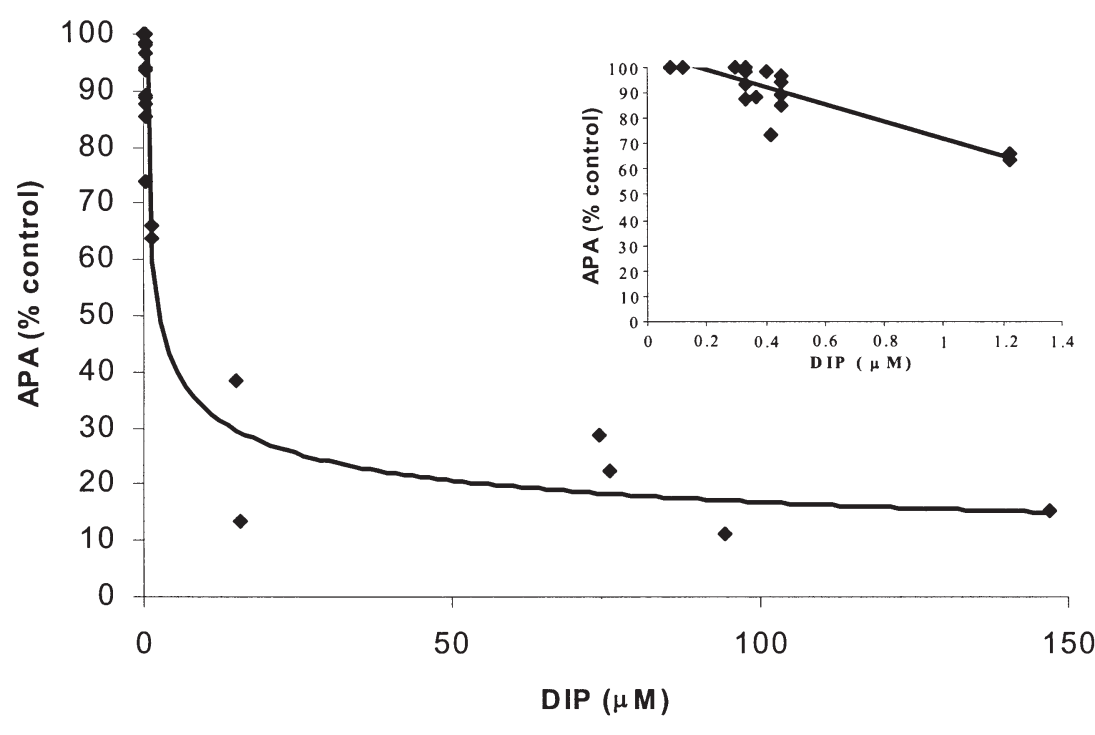

Fig. 3. Trichodesmium spp. Relationship between alkaline phosphatase activity (APA) and dissolved inorganic P (DIP) concentrations estimated during incubations of natural populations. Results are pooled from assays conducted on natural populations enriched with 10 to $150 \mathrm{mM}$ DIP (as $\mathrm{PO}_{4}{ }^{3-}$ ) during the November 1999 cruise 


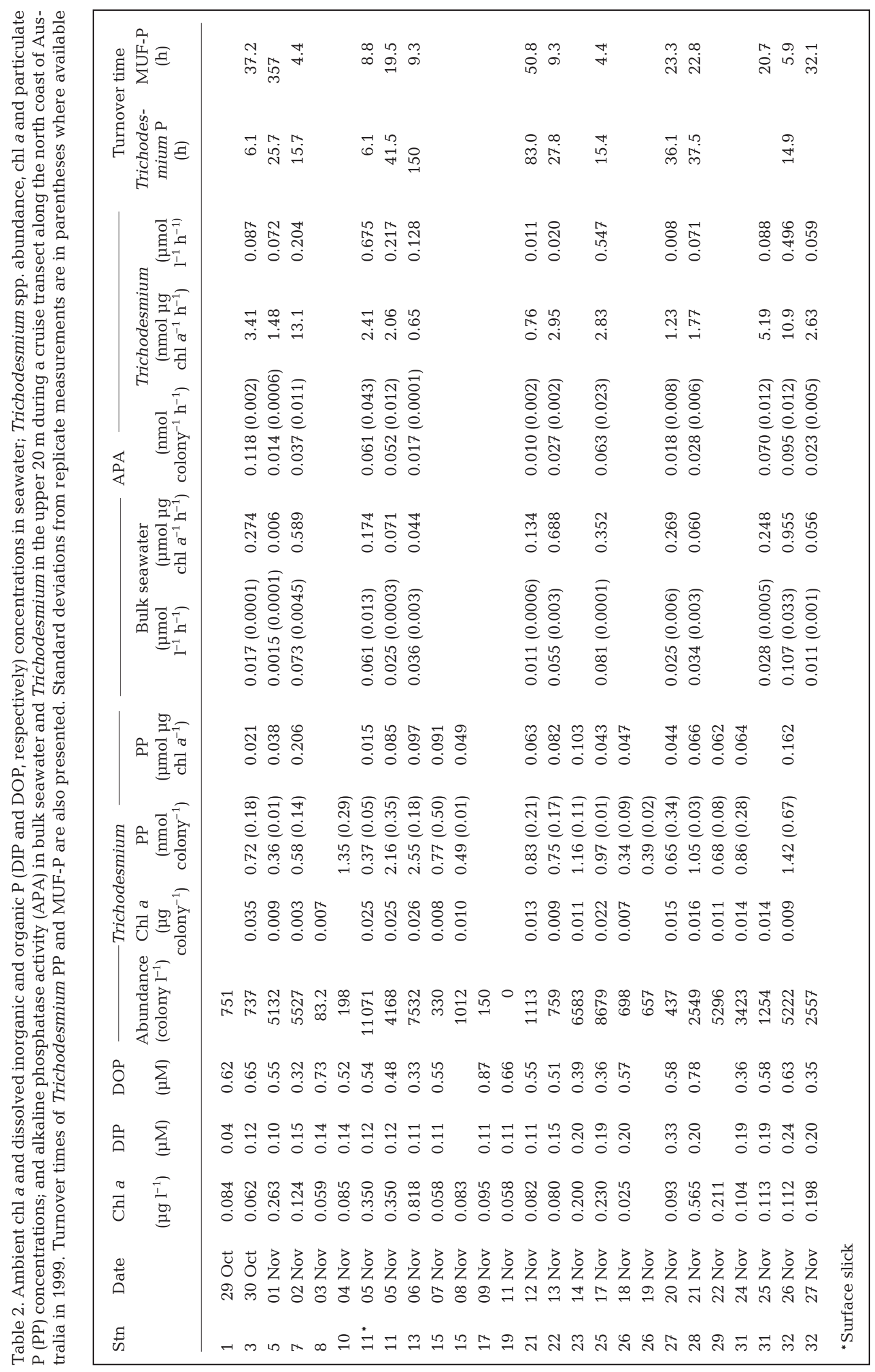



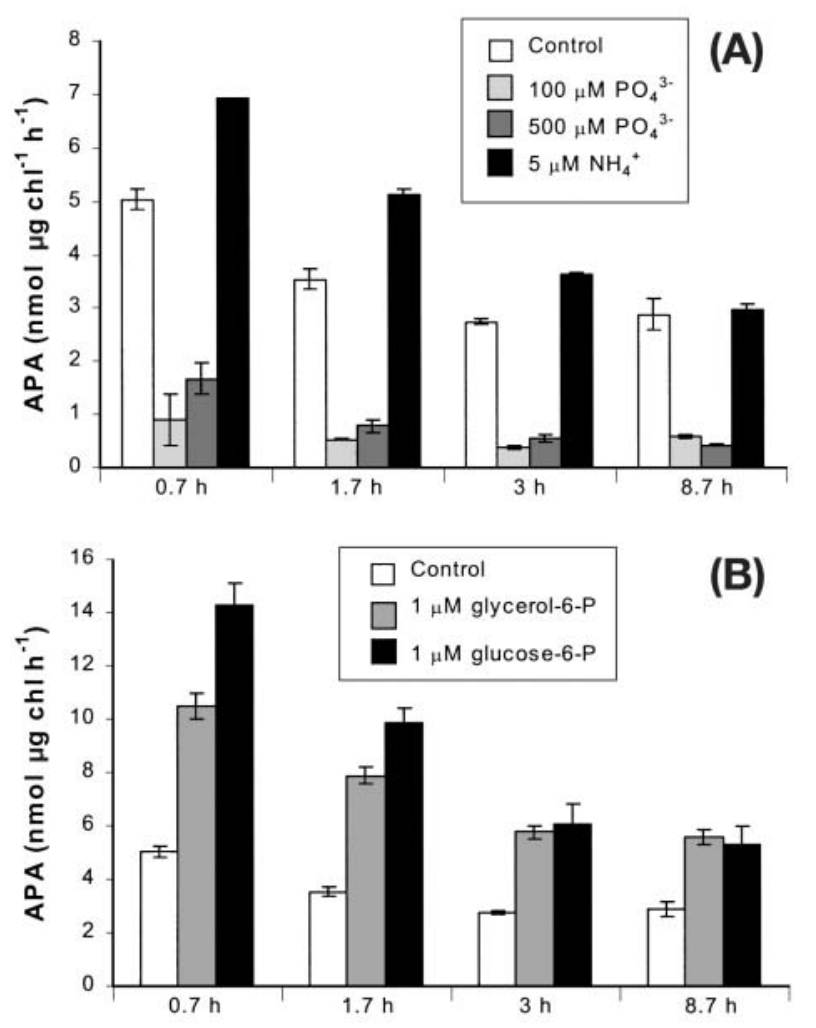

Fig. 4. Trichodesmium spp. APA in natural populations enriched with (A) DIP or $\mathrm{NH}_{4}{ }^{+}$, or (B) DOP (as Na-glycerolphosphate) over time-course incubations conducted on the November 1999 cruise. Error bars are \pm SD

tions and the turnover time of MUF-P for the November 1999 cruise along the north coast of Australia, assuming that APA was constant over a $24 \mathrm{~h}$ day (Table 2). The cellular $\mathrm{P}$ concentrations ranged from 0.34 to 2.55 nmol $\mathrm{P}$ colony ${ }^{-1}$. These numbers are similar to the tropical (0.51 nmol colony $\left.{ }^{-1}\right)$ and subtropical $\left(1.10 \mathrm{nmol}\right.$ colony ${ }^{-1}$ ) medians observed in the Atlantic during a previous study (Sañudo-Wilhelmy et al. 2001). We calculated that turnover times of Trichodesmium $\mathrm{P}$ biomass due to APA ranged from 6 to $150 \mathrm{~h}$ during the Australia transect. If we estimate Trichodesmium doubling times of 2 to $5 \mathrm{~d}$, then APA can supply a significant portion of the P necessary for growth.

During the Australia cruise, we performed treatment incubations to compare rates of APA among Trichodesmium colonies incubated with high concentrations of DIP, DOP and $\mathrm{NH}_{4}{ }^{+}$. Similar responses were observed in 5 sets of incubations; rates of APA were inhibited when DIP was added but enhanced when $\mathrm{NH}_{4}{ }^{+}$was added (Fig. 4A) and rates were enhanced with the addition of 2 different DOP substrates (Fig. 4B). Elevated rates of APA in response to $\mathrm{NH}_{4}{ }^{+}$additions, suggests that the supply of fixed $\mathrm{N}$ may limit $\mathrm{P}$ acquisition by APA in at least the short term. When we compared rates of APA by Trichodesmium over a diel cycle during the Australia transect, APA was highest during the morning and mid-day when $\mathrm{N}_{2}$ fixation rates were also high (Fig. 5A). In cultures, the diel pattern was not as pronounced, although rates were low during the middle of the dark period (Fig. 5B).

\section{Cultured populations}

Cultures of Trichodesmium IMS101 grew somewhat faster on DIP (as $\mathrm{PO}_{4}{ }^{3-}$ ) than on the organic P substrate, Na-glycerolphosphate (Fig. 6; cultures were unable to grow on glucose-6-phosphate, data not shown). The highest growth rates were observed on medium containing the highest concentration of DIP $(50 \mu \mathrm{M})$, and growth rates were comparable between cultures grown on $3 \mu \mathrm{M}$ DIP and 1 or $3 \mu \mathrm{M}$ DOP (as Na-glycerolphosphate; Fig. 6). Growth was much slower on medium enriched with $50 \mu \mathrm{M}$ DOP than on media with the lower concentrations of DOP (Fig. 6); however, inorganic $\mathrm{P}$ rapidly accumulated in the culture medium (Fig. 7A) while DOP decreased suggesting that APA facilitated DOP hydrolysis (Fig. 7C) even
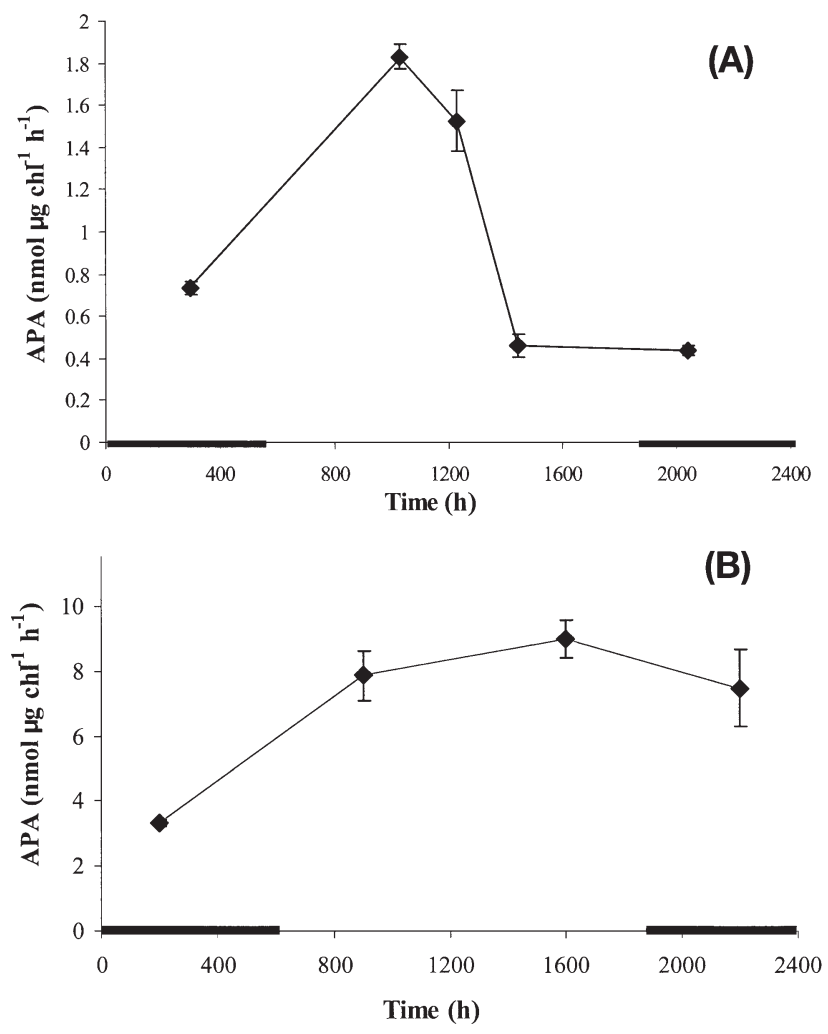

Fig. 5. Diel pattern of APA in (A) natural populations of Trichodesmium spp. collected on 25 and 26 November 1999 and (B) cultures of Trichodesmium IMS101. Error bars are \pm SD 
though the total chl a accumulation was low. In another study, growth rates of Trichodesmium IMS101 were comparable on $20 \mu \mathrm{M} \mathrm{PO}{ }_{4}{ }^{3-}$ and $20 \mu \mathrm{M}$ Na-glycerolphosphate (Stihl et al. 2001). At lower concentrations of DOP (e.g. 1 or $3 \mu \mathrm{M}$ ), DIP concentrations in the media increased initially (Fig. 7B) while DOP concentrations were depleted (Fig. 7D). Over time, the DIP produced in the media from DOP hydrolysis decreased, very likely because it was being taken up by growing cells.

In cultures grown on medium containing either 0, 1 or $3 \mu \mathrm{M}$ DIP, rates of APA increased with decreasing concentrations of DIP in the growth medium (Fig. 8; APA scaled for 1 and $3 \mu \mathrm{M}$ DIP treatments). When inorganic $\mathrm{P}$ in the culture medium was $50 \mu \mathrm{M}$, there was no detectable APA over the $22 \mathrm{~d}$ the cultures were monitored (data not shown) and DIP was never depleted from the culture medium. When cultures were grown on medium enriched in DOP, it was difficult to measure MUF-P hydrolysis because our MUF-P additions were small $(1 \mu \mathrm{M})$ relative to culture enrichments (1 to $50 \mu \mathrm{M})$. We estimated APA by the disappearance of DOP from the culture media (these are most likely

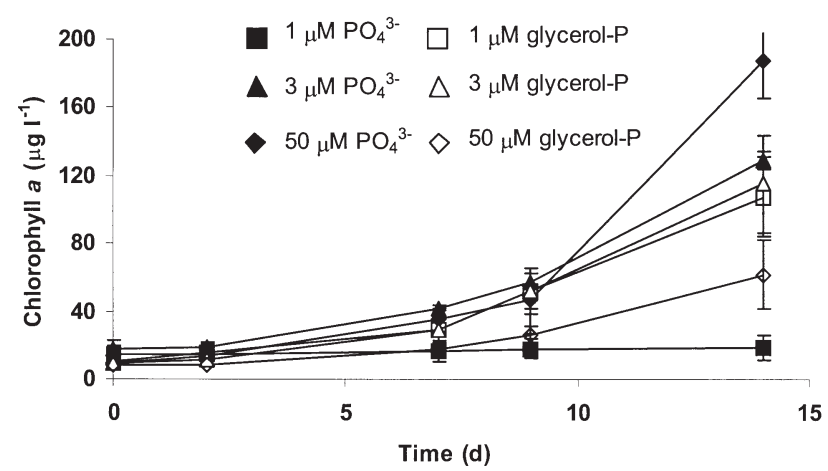

Fig. 6. Trichodesmium IMS101. Growth on media variably enriched with DIP (as $\mathrm{PO}_{4}{ }^{3-}$ ) or DOP (as Na-glycerolphosphate) over $14 \mathrm{~d}$. Error bars are $\pm \mathrm{SD}$

minimum APA estimates). Because DIP accumulated in the medium during growth on $50 \mu \mathrm{M}$ DOP, rates of APA must have exceeded the rate of uptake of the DIP produced. We therefore calculated the maximum turnover times for cellular P using the estimated rates of APA which were very fast, i.e. $0.1 \mathrm{~h}$ (Table 3 ).

(A)
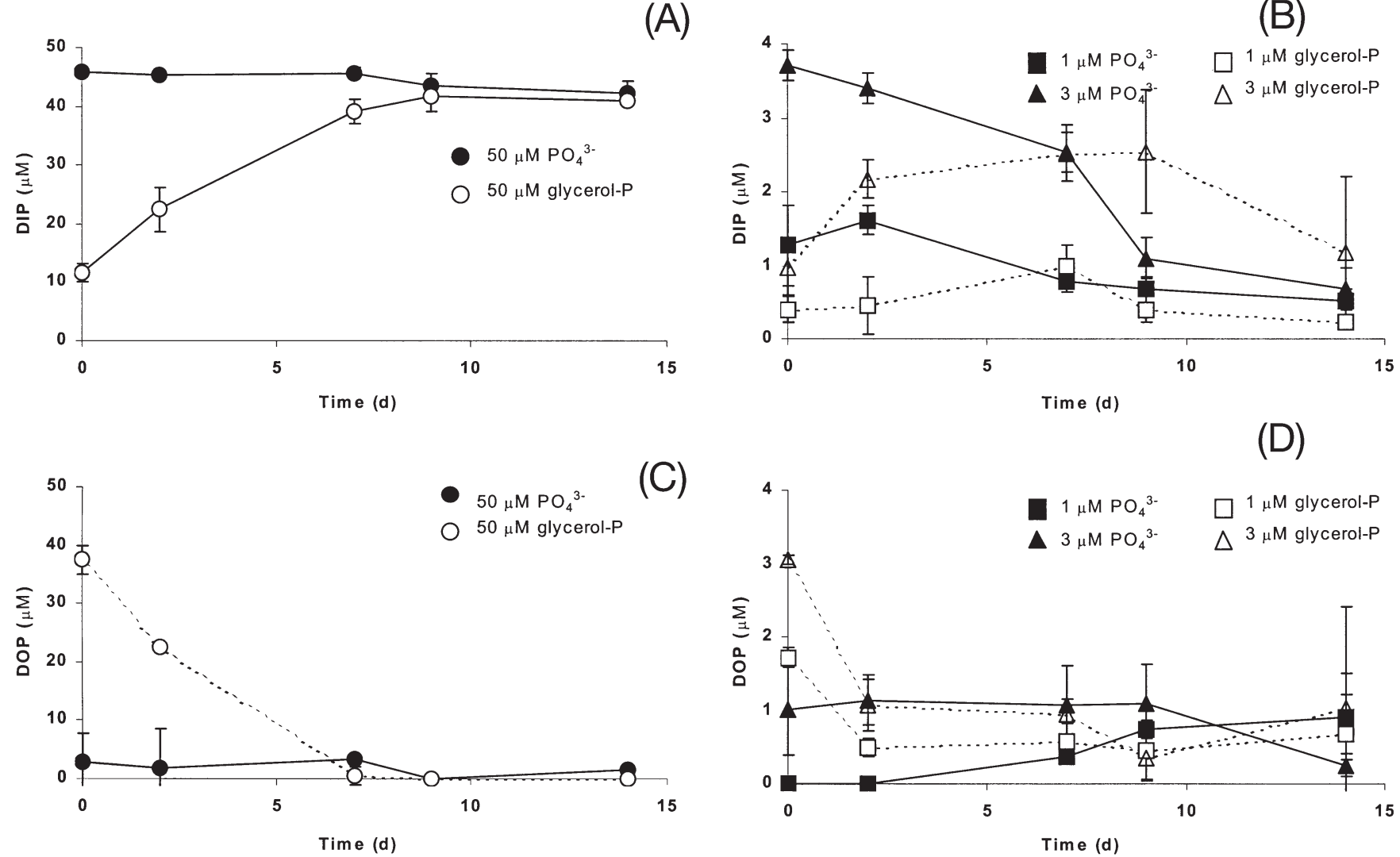

(D)

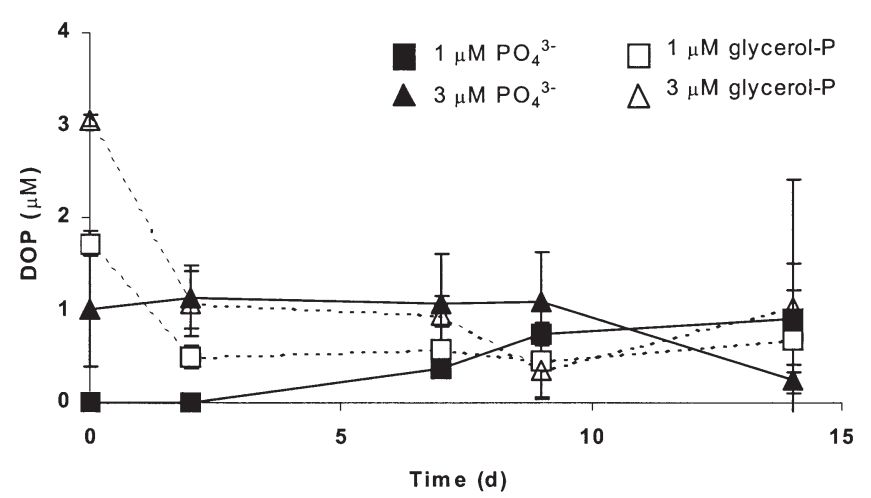

Fig. 7. Trichodesmium IMS101. Concentrations of (A,B) DIP and (C,D) DOP in Trichodesmium IMS101 cultures grown on media enriched with $(\mathrm{B}, \mathrm{D}) 1,3$ or $(\mathrm{A}, \mathrm{C}) 50 \mathrm{MM} \mathrm{PO}_{4}{ }^{3-}$ or Na-glycerolphosphate. Error bars are $\pm \mathrm{SD}$ 
Table 3. Cellular concentrations of particulate P (PP), PN:PP molar ratio, DOP and DIP concentrations, alkaline phosphatase activity (APA) and turnover of cellular P in culture experiments using Trichodesmium IMS101. Standard deviations for triplicate cultures are in parentheses. DL indicates the concentration was at the limit of analytical detection $(0.03 \mu \mathrm{M})$

\begin{tabular}{|c|c|c|c|c|c|c|c|c|}
\hline $\begin{array}{l}\text { Treatment } \\
\text { day }\end{array}$ & $\begin{array}{c}\text { PP } \\
\left(\mu \mathrm{mol} \mathrm{l} \mathrm{l}^{-1}\right)\end{array}$ & $\begin{array}{c}\text { PP } \\
(\mu \mathrm{mol} \mu \mathrm{g} \\
\left.\mathrm{chl} a^{-1}\right)\end{array}$ & $\begin{array}{l}\mathrm{PN}: \mathrm{PP} \\
\text { molar } \\
\text { ratio }\end{array}$ & $\begin{array}{l}\text { DOP } \\
(\mu M)\end{array}$ & $\begin{array}{c}\text { DIP } \\
(\mu \mathrm{M})\end{array}$ & $\begin{array}{c}\text { APA } \\
\left(\mu \mathrm{mol} \mathrm{l}^{-1} \mathrm{~h}^{-1}\right)\end{array}$ & $\begin{array}{c}\text { APA } \\
(\mu \mathrm{mol} \mu \mathrm{g} \\
\left.\mathrm{chl} a^{-1} \mathrm{~h}^{-1}\right)\end{array}$ & $\begin{array}{c}\text { Turnover } \\
\text { of cellular } \\
\text { (h) }\end{array}$ \\
\hline \multicolumn{9}{|c|}{1 pM glycerol-P } \\
\hline 0 & $0.08(0.03)$ & 0.018 & $26.2(16)$ & $1.7(0.1)$ & $2.4(0.2)$ & & & \\
\hline 3 & $0.08(0.02)$ & 0.015 & $140(8.1)$ & $0.5(0.1)$ & $2.5(0.4)$ & $0.008^{*}$ & 0.002 & 9.6 \\
\hline 6 & $0.14(0.10)$ & 0.019 & $110(34)$ & $0.6(0.2)$ & $1.0(0.3)$ & & & \\
\hline 11 & $0.16(0.05)$ & 0.020 & $72.0(0.8)$ & $0.4(0.2)$ & $0.4(0.2)$ & & & \\
\hline 14 & $0.26(0.03)$ & 0.021 & $41.5(6.0)$ & $0.7(0.5)$ & $0.2(0.05)$ & & & \\
\hline 22 & $0.62(0.17)$ & 0.031 & $23.6(1.5)$ & & & & & \\
\hline \multicolumn{9}{|c|}{3 pM glycerol-P } \\
\hline 0 & $0.04(0.01)$ & 0.009 & $150(87)$ & $3.0(0.1)$ & $3.0(0.4)$ & & & \\
\hline 3 & $0.08(0.02)$ & 0.022 & $156(82)$ & $1.1(0.3)$ & $4.2(0.3)$ & $0.050^{*}$ & 0.009 & 1.6 \\
\hline 6 & $0.23(0.02)$ & 0.037 & $111(57)$ & $1.0(0.6)$ & $3.5(0.4)$ & & & \\
\hline 11 & $0.31(0.04)$ & 0.043 & $88.7(28)$ & $0.4(0.3)$ & $2.5(0.8)$ & & & \\
\hline 14 & $0.44(0.04)$ & 0.033 & $118(60)$ & $0.2(0.4)$ & $1.2(1.0)$ & & & \\
\hline 22 & $0.78(0.05)$ & 0.035 & $23.8(0.8)$ & & & & & \\
\hline \multicolumn{9}{|c|}{$50 \mu \mathrm{M}$ glycerol-P } \\
\hline 0 & $0.22(0.05)$ & 0.049 & $35.2(5.0)$ & $34(3.0)$ & $11.8(1.5)$ & & & \\
\hline 3 & $0.28(0.02)$ & 0.062 & 12.9 & $23(6.7)$ & $22.4(3.8)$ & $3.381^{*}$ & 0.626 & 0.1 \\
\hline 6 & $0.30(0.06)$ & 0.083 & $4.37(2.4)$ & $0.5(0.3)$ & $39.2(2.0)$ & & & \\
\hline 11 & $0.57(0.04)$ & 0.158 & $20.2(2.7)$ & DL & $41.6(2.4)$ & & & \\
\hline 14 & $0.90(0.04)$ & 0.101 & $23.9(2.4)$ & $\mathrm{DL}$ & $41.0(0.6)$ & & & \\
\hline 22 & $1.09(0.10)$ & 0.094 & $5.7(4.7)$ & & & & & \\
\hline
\end{tabular}

Cellular P concentrations increased and the cellular PN:PP molar ratio decreased in cultures enriched with organic P suggesting that organic P alleviated P limitation and promoted P uptake and growth. However, PN:PP ratios were near Redfield only in cultures growing on $50 \mu \mathrm{M}$ DOP (Fig. 9A) or those growing on 3 or $50 \mu \mathrm{M}$ DIP (Fig. 9B). The cellular PN:PP ratios were highest in the cultures grown on 1 or $3 \mu \mathrm{M}$ DOP and ratios increased as $\mathrm{P}$ was depleted in cultures growing on low DIP (e.g. $1 \mu \mathrm{M})$.

\section{DISCUSSION}

As for other species, APA by Trichodesmium is sensitive to environmental DIP concentrations; activity appears to be inhibited when concentrations of DIP are high. In this study, chl a-specific rates of APA by Trichodesmium were higher in the Atlantic Ocean than along the north coast of Australia, including several stations in the Coral Sea. This is consistent with the relative depletion of DIP in the Atlantic Ocean during our cruises. Recently, it has been argued that the North Atlantic is more severely $\mathrm{P}$ limited than the Pacific and our results for the Atlantic would indicate a very high level of $\mathrm{P}$ stress (Wu et al. 2000, Sañudo-Wilhelmy et al. 2001).
In addition, we determined that for 2 geographically distinct populations of Trichodesmium, levels of APA vary dramatically, and this may reflect the relative availability of labile P sources for growth and the physiological status of cells. Much higher per colony rates of APA were found in Trichodesmium populations from the tropical Atlantic, where DIP concentrations were an order of magnitude lower, compared to populations in waters along the north coast of Australia. Trichodesmium colonies from both the Atlantic and Australian coastal waters exhibited lower rates of APA than those from the Gulf of Aqaba, where DIP concentrations were at or near the limits of analytical detection (Stihl et al. 2001). It is difficult to make quantitative comparisons between this and the other study, however, because the APA assays used different substrates and were performed under different conditions. In particular, the Stihl et al. (2001) study employed assays using saturating additions of PNPP $(0.4 \mu \mathrm{M})$ and these were performed over $12 \mathrm{~h}$ incubations at $37^{\circ} \mathrm{C}$ (optimum temperature for enzyme activity), and so their results are likely maxima. An advantage of using saturating additions is that competition with ambient DOP pools does not greatly affect the ability to observe hydrolysis of the model substrate, but a disadvantage is that in situ rates can be overestimated. 

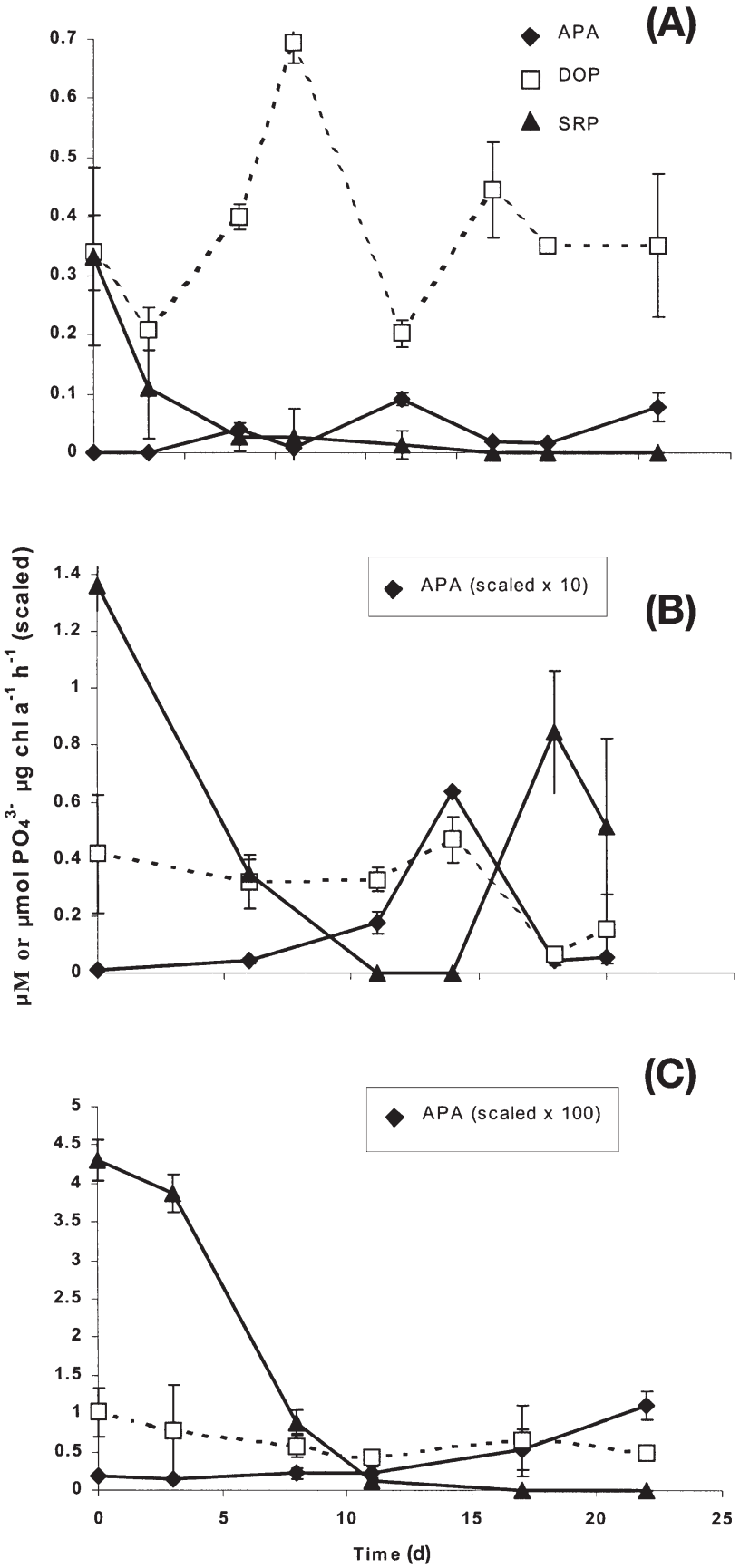

Fig. 8. Trichodesmium IMS101. Relationship between DIP, DOP, and APA activity in Trichodesmium IMS101 grown on medium with (A) no added DIP, (B) $1 \mu \mathrm{M}$ DIP (APA scaled by a factor of 10) or (C) $3 \mu \mathrm{M}$ DIP (APA scaled by a factor of 100). Error bars are $\pm \mathrm{SD}$

Despite lower chl a specific APA rates, colonies were more abundant, although smaller, along the north coast of Australia, and so volumetric rates of APA were higher than those estimated from the Atlantic; Trichodesmium-associated APA represented the bulk of the water column APA at most stations (Table 2). Concentrations of DOP along the Australia transect ranged from 0.32 to $0.87 \mu \mathrm{M}$ and this may have also stimulated APA. In natural populations, additions of DIP inhibited APA while additions of DOP enhanced APA. Concentrations of DOP were not measured in the Atlantic or reported for the Gulf of Aqaba study (Stihl et al. 2001) and so the extent to which DOP stimulates APA in nature could not be assessed.

Our results demonstrate that Trichodesmium IMS101 can grow well using the DOP substrate, Naglycerolphosphate, and that APA varies as a function of $\mathrm{P}$ availability in the culture medium. These results are consistent with another recent study where growth rates of Trichodesmium IMS101 were comparable on $20 \mu \mathrm{M}$ concentrations of either DIP $\left(\right.$ as $\mathrm{PO}_{4}{ }^{3-}$ ) or DOP (as Na-glycerolphosphate; Stihl et al. 2001). Based on the cellular P concentrations and rates of APA, we estimate that Trichodesmium can meet its $\mathrm{P}$ demand for growth by using DOP if DOP is in adequate supply. Estimates of doubling times for natural populations of Trichodesmium range between 3 and several $100 \mathrm{~d}$ (Carpenter 1983, Mulholland \& Capone 2001); cultured Trichodesmium have doubling times that range
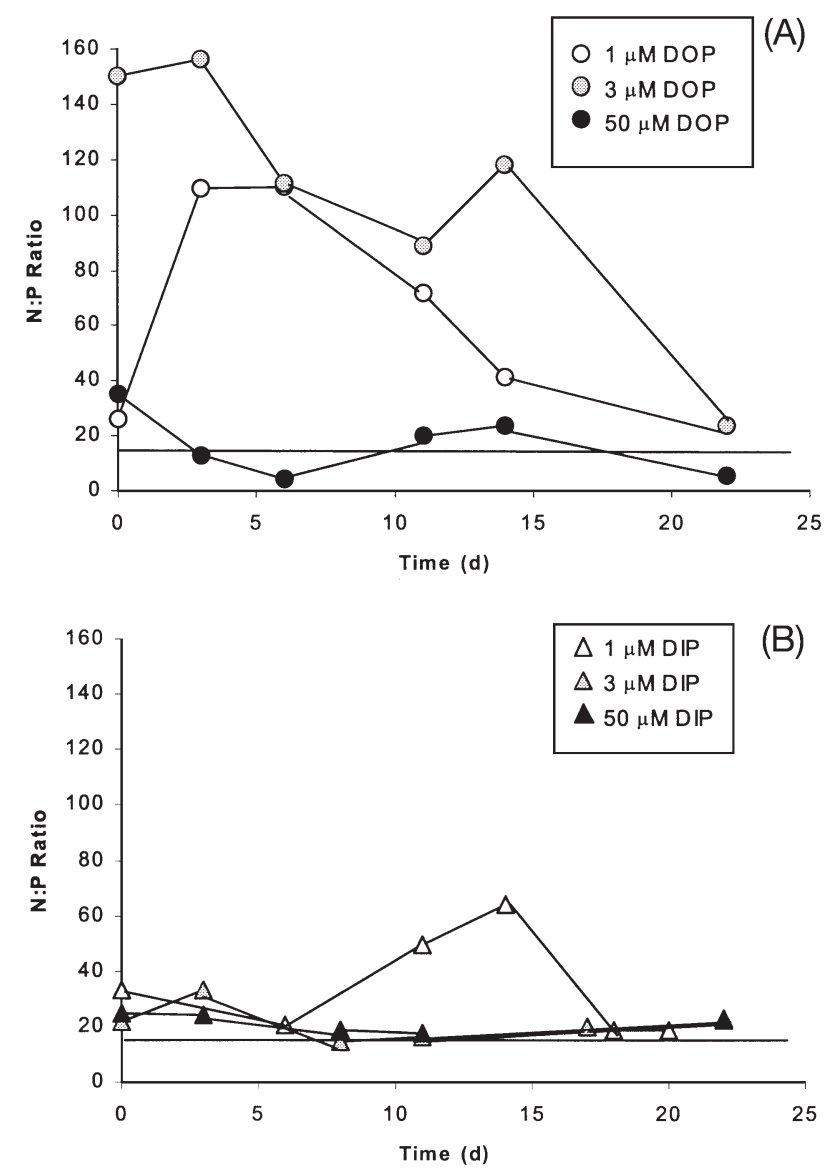

Fig. 9. Trichodesmium IMS101. N:P ratios in Trichodesmium IMS101 grown on medium with (A) 1, 3 or $50 \mu \mathrm{M}$ DOP (as Na-glycerolphosphate) or (B) 1, 3 or $50 \mu \mathrm{M}$ DIP (as $\mathrm{PO}_{4}{ }^{3-}$ ) 
from 1 to $10 \mathrm{~d}$ (Ohki et al. 1992, Mulholland \& Capone 2000). Our estimates of potential cellular P turnover times due to APA ranged from 6.1 to $150 \mathrm{~h}$, suggesting that APA can potentially supply nearly all of the P demand for growth, if the available DOP supply is sufficient.

These results have important implications with regard to Trichodesmium growth in natural systems. Abell et al. (2000) calculated that DOP concentrations and turnover in the Pacific could meet Trichodesmium P demand based on $\mathrm{N}_{2}$ fixation. We confirm that this is physiologically plausible if there are sufficient DOP substrates available for hydrolysis. However, the quality and relative availability of DOP in the marine environment is largely unknown. In cultures of Trichodesmium IMS101, 2 DOP substrates were tested, Na-glycerolphosphate and glucose-6-phosphate, but only the former yielded culture growth. In this study, we assumed that the entire DOP pool was available for hydrolysis and this is not likely to be the case. Therefore, our turnover times should be considered as maxima.

There are few studies that have investigated the kinetics of non-nitrogenous nutrient uptake by Trichodesmium. In the only kinetic study published regarding $\mathrm{P}$ uptake, it was demonstrated that Trichodesmium have a low affinity for orthophosphate $\left(K_{\mathrm{s}}=\right.$ $9 \mu \mathrm{M})$ but a high potential for utilizing phosphomonoesters (170 to $300 \mathrm{nmol} \mathrm{P} \mu \mathrm{g} \mathrm{chl} a^{-1} \mathrm{~h}^{-1}$; McCarthy \& Carpenter 1979). We observed that in cultures, Trichodesmium IMS101 grew rapidly when supplied with high concentrations of DIP $(50 \mu \mathrm{M})$. Growth rates and biomass accumulation were lower when DIP was supplied at lower concentrations ( 1 to $3 \mu \mathrm{M}$ ) or when DOP was the sole source of P for growth. However, APA was not observed in cultures until the DIP pool was depleted and even low concentrations of DIP supported significant growth. This suggests that the affinity for DIP may be higher than previously thought. We did not measure $\mathrm{P}$ uptake kinetics during this study. High rates of APA in cultures growing on DOP resulted in the accumulation of DIP in the culture medium, suggesting that rates of APA exceeded rates of DIP uptake. This also suggests that APA does not limit DIP uptake when there is sufficient available DOP. Inorganic $\mathrm{P}$ has been shown to accumulate under bloom conditions (Devassy et al. 1978, Letelier \& Karl 1998). It is unlikely that DIP is directly released by Trichodesmium and therefore, we speculate that accumulation of DIP is most likely the result of hydrolysis of organic $\mathrm{P}$ by Trichodesmium or associated taxa.

A scenario referred to as 'P mining' has been suggested as a mechanism whereby Trichodesmium spp. might acquire the necessary $\mathrm{P}$, as DIP, for growth in natural systems. Essentially, this mechanism involves vertical migration of Trichodesmium, on some time scale, down to the phosphocline where they take up DIP, store it as polyphosphate granules and then buoy up to the surface where $\mathrm{N}_{2}$ fixation can be energetically supported by photosynthesis (Karl et al. 1992, Hood et al. 2000). This theory is supported by observations that Trichodesmium can physiologically regulate their buoyancy (Romans et al. 1994); however, it is counterintuitive in that cells rich in polyphosphate bodies would most likely be heavier than those deplete in P. In one study, sinking colonies collected in the Atlantic were replete in $\mathrm{C}$ and $\mathrm{P}$ reserves, while rising colonies had low reserves of both elements, suggesting that ' $\mathrm{P}$ mining' does not occur (Romans et al. 1994). Alternatively, if buoyancy regulation is effected through $\mathrm{C}$ reserves or some other physiological factor such as gas exchange, than this mechanism might be possible. Carbon reserves were responsible for the major fraction of density ballasting in the study by Romans et al. (1994), and it is possible that in the Pacific Ocean, sinking cells have low $\mathrm{P}$ reserves and engage in 'P mining'.

Cells that are able to hydrolyze DOP and compete for the hydrolysis products may be able to acquire sufficient $\mathrm{P}$ in the photic zone if there are adequate supplies of available DOP. Trichodesmium IMS101, the most widely available clone of this species, has been tentatively identified as $T$. erythraeum based on genetic and cytomorphological observations (Jansen et al. 1995, 1999). This species is positively buoyant because it has abundant gas vesicles and its ability to take advantage of DOP may allow it to compete for limited $P$ resources in the surface waters of the oligotrophic ocean, precluding the need to vertically migrate to the phosphocline.

Our results from culture studies confirm that Trichodesmium IMS101 can grow when DOP is the sole source of P. However, low cellular P concentrations and high PN:PP ratios result from growth on low concentrations of DOP or from DIP limitation of growth. When ambient DIP concentrations are low or at the limit of analytical detection, natural populations of Trichodesmium can hydrolyze DOP at high rates. This suggests that so long as there is an adequate supply of either DIP or DOP, surface populations can acquire P for growth without needing to 'mine' $\mathrm{P}$ at or below the phosphocline.

Acknowledgements. The authors would like to thank Laura Sprague, Jamie Krauk and Jay Burns for their help in analyzing these samples. In addition, Skip Stiles and Rachel Foster are thanked for their assistance in the laboratory. We thank Linda Farmer for assistance aboard the RV 'Gyre', and the captain and crew of the RV 'Gyre' and the RV 'Maurice Ewing'. We also thank 3 anonymous reviewers for their thoughtful comments on the manuscript. This work was supported by NSF Grants to D.G.C. and E.J.C. 


\section{LITERATURE CITED}

Abell J, Emerson S, Renaud P (2000) Distributions of TOP, TON and TOC in the North Pacific subtropical gyre: implications for nutrient supply in the surface ocean and remineralization in the upper thermocline. J Mar Res 58: 203-222

Ammerman JW (1993) Microbial cycling of inorganic and organic phosphorus in the water column. In: Kemp PF, Sherr BF, Sherr EB, Cole JJ (eds) Handbook of methods in aquatic microbial ecology. Lewis Publishers, Boca Raton, FL, p 649-660

Capone DG, Zehr JP, Paerl HW, Bergman B, Carpenter EJ (1997) Trichodesmium, a globally significant marine cyanobacterium. Science 276:1221-1229

Carpenter EJ (1983) Physiology and ecology of marine planktonic Oscillatoria (Trichodesmium). Mar Biol Lett 4:69-85

Carpenter EJ, Capone DG, Fry B, Harvey HR (1997) Biogeochemical tracers of the marine cyanobacterium Trichodesmium. Deep-Sea Res 44:27-38

Chen YB, Zehr JP, Mellon M (1996) Growth and nitrogen fixation of the diazotrophic filamentous nonheterocystous cyanobacterium Trichodesmium sp. IMS101 in defined media: evidence for a circadian rhythm. J Phycol 32: 916-923

Devassy VP, Bhattathiri PMA, Qasim SZ (1978) Trichodesmium phenomenon. Indian J Mar Sci 7:168-186

Dugdale RC, Goering JJ (1967) Uptake of new and regenerated forms of nitrogen in primary productivity. Limnol Oceanogr 12:196-206

Falkowski PG (1997) Evolution of the nitrogen cycle and its influence on the biological sequestration of $\mathrm{CO}_{2}$ in the ocean. Nature 387:272-275

Hood RR, Michaels AF, Capone DG (2000) Answers sought to the enigma of marine nitrogen fixation. EOS Trans Am Geophys Union 81:133, 138-139

Jansen S, Siddiqui RJA, Walsby AE, Romans KM, Carpenter EJ, Bergman B (1995) Cytomorphological characterization of the planktonic diazotrophic cyanobacteria Trichodesmium spp. from the Indian Ocean and Caribbean and Sargasso Seas. J Phycol 31:463-477

Jansen S, Jansen S, Bergman B, Carpenter EJ, Giovannoni SJ, Vergin K (1999) Genetic analysis of natural populations of the marine diazotrophic cyanobacterium Trichodesmium. FEMS Microbiol Ecol 30:57-65

Karl DM (1999) A sea of change: biogeochemical variability in the North Pacific Subtropical Gyre. Ecosystems 2:181-214

Karl DM, Letelier RM, Hebel DB, Bird DF, Winn CD (1992) Trichodesmium blooms and new nitrogen in the North Pacific Gyre. In: Carpenter EJ, Capone DG, Rueter JG (eds) Marine pelagic cyanobacteria: Trichodesmium and other diazotrophs. Kluwer Academic Publishers, Dordrecht, p 219-237

Karl DM, Letelier RM, Tupas L, Dore J, Christian J, Hebel D (1997) The role of nitrogen fixation in biogeochemical cycling in the subtropical North Pacific. Nature 388: 533-538

Karl DM, Björkman KM, Dore JE, Fujieki L, Hebel DB, Houlihan T, Letelier RM, Tupas LM (2001) Ecological nitrogento-phosphorus stoichiometry at station ALOHA. Deep-Sea Res 48:1529-1566

Editorial responsibility: Otto Kinne (Editor),

Oldendorf/Luhe, Germany
Letelier RM, Karl DM (1996) Role of Trichodesmium spp. in the productivity of the subtropical North Pacific Ocean. Mar Ecol Prog Ser 133:263-273

Letelier RM, Karl DM (1998) Trichodesmium spp. physiology and nutrient fluxes in the North Pacific subtropical gyre. Aquat Microb Ecol 15:265-276

Mackinney G (1941) Absorption of light by chlorophyll solutions. J Biol Chem 140:315-322

McCarthy JJ, Carpenter EJ (1979) Oscillatoria (Trichodesmium) thiebautii (Cyanophyta) in the central North Atlantic Ocean. J Phycol 15:75-82

Mulholland MR, Capone DG (2000) The physiology of the marine $\mathrm{N}_{2}$ fixing cyanobacteria Trichodesmium. Trends Plant Sci 5:148-153

Mulholland MR, Capone DG (2001) The stoichiometry of N and $\mathrm{C}$ utilization in cultured populations of Trichodesmium IMS101. Limnol Oceanogr 46:436-443

Ohki K, Zehr JP, Fujita Y (1992) Trichodesmium: establishment of culture and characteristics of $\mathrm{N}_{2}$ fixation. In: Carpenter EJ, Capone DG, Rueter JG (eds) Marine pelagic cyanobacteria: Trichodesmium and other diazotrophs. Kluwer Academic Publishers, Dordrecht, p 307-318

Parsons TR, Maita Y, Lalli C (1984) A manual of chemical and biological methods for seawater analysis. Pergamon Press, Oxford

Perry MJ (1972) Alkaline phosphatase activity in subtropical Central North Pacific waters using a sensitive fluorometric method. Mar Biol 15:113-119

Raimbault P, Diaz F, Pouvesle W, Boudjellal B (1999) Simultaneous determination of particulate organic carbon, nitrogen and phosphorus collected on filters, using a semiautomatic wet-oxidation method. Mar Ecol Prog Ser 180: 289-295

Reuter JG, Hutchins DA, Smith RW, Unsworth NL (1992) Iron nutrition of Trichodesmium. In: Carpenter EJ, Capone DG, Rueter JG (eds) Marine pelagic cyanobacteria: Trichodesmium and other diazotrophs. Kluwer Academic Publishers, Dordrecht, p 289-306

Romans KM, Carpenter EJ, Bergman B (1994) Buoyancy regulation in the colonial diazotrophic cyanobacterium Trichodesmium tenue: ultrastructure and storage of carbohydrate, polyphosphate and nitrogen. J Phycol 30: 935-942

Sañudo-Wilhelmy SA, Kustka AB, Gobler CJ, Hutchins DA and 6 others (2001) Phosphorus limitation of nitrogen fixation by Trichodesmium in the central Atlantic Ocean. Nature 411:66-69

Stihl A, Sommer U, Post AF (2001) Alkaline phosphatase activities among populations of the colony-forming diazotrophic cyanobacterium Trichodesmium spp. (Cyanobacteria) in the Red Sea. J Phycol 37:310-317

Valderrama JC (1981) The simultaneous analysis of total nitrogen and total phosphorus in natural waters. Mar Chem 10:109-122

Wu J, Sunda W, Boyle EA, Karl DM (2000) Phosphate depletion in the Western North Atlantic Ocean. Science 289: 759-762

Yentsch CM, Yentsch CS, Perras JP (1972) Alkaline phosphatase activity in the tropical marine blue-green alga Oscillatoria erythraea ('Trichodesmium'). Limnol Oceanogr $17: 772-774$

Submitted: November 26, 2001; Accepted: April 30, 2002

Proofs received from author(s): August 6, 2002 